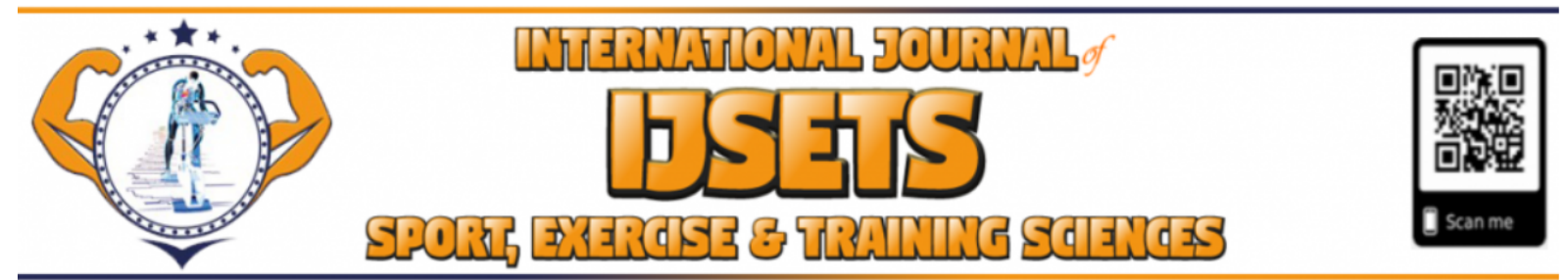

\begin{tabular}{ccc}
\hline e-ISSN 2149-8229 & Vol 7, Issue 3, 100-113, (2021) & Original Article \\
\hline http://dergipark.gov.tr/useeabd &
\end{tabular}

\title{
Towards the Artificial Intelligence Management in Sports
}

\author{
Berkan ATASOY ${ }^{1}$, Mehmet EFE ${ }^{2}$, Varol TUTAL ${ }^{3}$,
}

Abstract
Aim: This paper discusses the new technological developments in artificial intelligence
embracing the world and aims to offer an overview as well as some evaluations of positive and
negative effects on sports.
Methods: This paper discusses different types of reviews and articles by using literature review
and description method, to offer an overview, proposition, comparison and critic on topic.
Conceptual framework: The current technology which is developing around the world is
making revolutionary progress in the field of sports. Especially the development of technology
and the use of Artificial Intelligence provide to individuals and the society new opportunities for
sports and sports management. This situation paves the way for efficient and effective
management in sports by allowing sports managers to include certain levels of technology in
decision-making processes. In line with these developments, if the administrators benefit at the
highest level, the development in the field of sports will be able to move forward with a more
dynamic acceleration. For the development of sports, it is possible to make a path towards
predictive and accurate decisions by using Artificial Intelligence models developed in the field of
sports around the world to prevent problems before they arise. For this purpose, in this literature
review, new technological developments in artificial intelligence covering the world sports
service and industry are scanned and examined in terms of the positive and negative effects of
artificial intelligence in sports. In the study, it is concluded that sports field is now in the phase
of being under the influence of artificial intelligence. Some evaluations and suggestions are
presented in this direction.

Conclusion: The artificial intelligence usage in sports and sports related event may have incredible assistance for reliable and precised games or competitions. However, in case of unlimited usage of technological opportunity in human life, today's sports, whose base is essentially human, may be in danger.

\begin{tabular}{lr}
\hline Sporda Yapay Zeka Yönetimine Do ğru & Keywords \\
Özet & Yapay Zeka (YZ), \\
Amaç: Bu makale, dünyayı kapsayan yapay zeka alanındaki yeni teknolojik gelişmeleri & Spor, \\
tartışmakta ve spor üzerindeki olumlu ve olumsuz etkilerine dair bazı değerlendirmelerin yanı & Yönetim, \\
sıra, genel bir bakış sunmayı amaçlamaktadır. & Teknoloji, \\
Yöntem: Çalışmada, konuyla ilgili bir genel bakış, öneri, karşılaştırma ve eleştiri sunmak için &
\end{tabular}

farklı türdeki derlemeleri ve makaleleri tartışmayi amaçlayan, literatür tarama yöntemi kullanılmıştır.

Kavramsal Çerçeve: Günümüzde gelişen teknolojinin toplumlar tarafından benimsenerek yaygın kullanması, spor alanında da devrimsel yeniliklere yol açmaktadır. Gelişen teknoloji ve bu teknolojinin bireylere ve topluma sunduğu Yapay Zekâ kullanımı, spor ve spor yönetimine de yeni firsatlar sunmaktadır. Bu durum spor yöneticilerinin karar alma süreçlerinde belirli düzeylerde teknolojinin de yer almasına izin verilmesiyle, sporda verimli ve etkin yönetimin önü açılmaktadır. Bu gelişmelerin doğrultusunda yöneticilerin de en üst düzeyde faydalanması durumunda, ülkemizin spor alanındaki gelişimi daha dinamik bir ivmelenme ile ileriye taşınması mümkün olacaktır. Spordaki gelişim için, spor yöneticilerinin dünyada spor alanında geliştirilen Yapay Zekâ modellerinden faydalanarak, daha problemler türemeden problemleri engelleme gibi, öngörülü ve isabetli kararlara doğru bir yol açılması mümkündür. Bu amaçla mevcut betimsel çalışmada, dünya spor hizmetini ve endüstrisini kapsayan yapay zeka alanındaki yeni teknolojik gelișmeler taranmıș ve yapay zekanın spordaki olumlu ve olumsuz etkileri incelenmeye çalışılmıştır. Çalışmamızda sporun da artık yapay zeka etkisine girme aşamasında olduğu sonucuna ulaşılarak, bu doğrultuda bazı değerlendirme ve öneriler sunulmaya çalışılmıştır.

Sonuç: Yapay Zeka'nın spor etkinliklerinde ve çevresinde kullanılması, güvenilir ve hassas bir DOI:10.18826/useeabd.845994 maç için inanılmaz bir yardım sağlayabilir. Ancak teknolojik imkanların insan hayatında sınırsız kullanılması durumunda, temeli esasen insan olan günümüz spor olgusu tehlikeye atılabilecektir.

The role and contributions of each authors as in the section of IJSETS Writing Rules "Criteria for Authorship" is reported that: 1. Author: Contributions to the conception or design of the paper, data collection, statistical analysis, interpretation of the data, writing of the paper; 2 . Author: Design of the paper, writing of the paper, statistical analysis; 3. Author:, Contributions to the conception of the paper, final approval of the version to be published paper;

${ }^{1}$ Corresponding Author: Gençlik ve Spor Bakanlığı, Ankara/Turkey, berkant atasoy@hotmail.com ORCID ID: 0000-0002-1684-1889

${ }^{2}$ Siirt University, Siirt/Turkey, mehmetefe18@hotmail.com ORCID ID: 0000-0003-2247-586X

${ }^{3}$ Siirt University, Siirt/Turkey, v.tutal@hotmail.com ORCID ID: 0000-0001-5647-9370 


\section{INTRODUCTION}

Since the conscious discovery of fire, human beings have encountered many revolutionary developments and inventions in the historical process and have managed to adapt these new inventions to their own lifestyles and used them for continuous development in the individual and social field. Today, it is seen that there is a brand-new ground-breaking development of humankind; Artificial intelligence (AI). This new concept, which emerged with the development of today's technologies, is a candidate for completely changing individual and social life.

Until today's Artificial Intelligence management, many institutions and organizations have had the opportunity to benefit from the development in the field of management such as Total Quality Management, Database Management, Customer Relationship Management, Digital Management, etc. However, Artificial Intelligence studies that developed today promise switching to a new management model, including the advantages of the previous management styles. This new Artificial intelligence model provides a technology for analysis, reporting and automation by storing data obtained from many interrelated or unrelated elements in an ecosystem.

The effects of artificial intelligence and its applications are already felt in many areas of today's professional and social life. Now, many enterprises, institutions and organizations, which are included in the economic structure of the countries, are taking steps towards more efficient and effective use of resources by directing their knowledge and resources to managerial structures that act in coordination with artificial intelligence. Looking to the global applications, it can be said that the sports industry is now also affected by these developments, but has not yet been able to benefit widely from the comprehensive applications brought by artificial intelligence. However, it is expected that with the advancement and the developments provided in time, artificial intelligence will penetrate deeply into every field of sports and cause radical changes. As a matter of fact, today some sporting equipment and wears that can collect data from their users, team management software that can analyse and programs the jobs, tasks and services, are pointing only the beginning stage of artificial intelligence. Extensive data and information flow derived from the infrastructure of the sports industry has formed the basis of artificial intelligence in sports and it is paving the way for taking steps towards the future.

It is known that societies that can improve technology are always at the forefront of the world stage. Artificial intelligence field studies, which are one of the most important developments of today, also offer important opportunities to societies. Considering the fact that in the future countries will be directing their sport organizations with artificial intelligence, we can say that they will be closer to success. At this point, conducting such studies from today before artificial intelligence applications in sports that have become widespread will contribute to the society by enabling predictions for the future of sports. The current study tries to emphasize the importance for young researchers working in the field of sports to develop new perspectives for the future of sports. In order to understand the contribution of artificial intelligence and communication technologies in the field of sports and to ensure a prepared and uninterrupted transition to this change, the importance of relevant field studies is increasing.

In this study, it is aimed to examine the artificial intelligence in sports, its usage area, the possibility of use in sports branches, and advantages or disadvantages in the future. This study aims to create a descriptive resource for artificial intelligence models and applications, developed in the field of sports. In this context, with this literature review the usage areas of artificial intelligence in sports and the possible contributions of developing artificial intelligence technologies to sports management are represented.

\section{CONCEPTUAL FRAMEWORK}

\section{Definitions of Artificial Intelligence}

Since computer scientist John McCarthy coined the term "artificial intelligence" for the first time at a conference at Dartmouth University in 1956, the invincible adventure of human beings against machine intelligence came to an end when the first super computers of the period Deep Blue developed by IBM defeated the world chess champion Garry Kasparov in 1997 (Karaduman, 2019).

There are many definitions of artificial intelligence. The fact that artificial intelligence is associated with human beings, which is defined as the most developed intelligent being living on earth, leads us to the definition of human intelligence. According to the Turkish Language Association (2020), 
intelligence has been defined as "all abilities of human thinking, reasoning, perception of objective facts, comprehension, judgment and drawing conclusions". According to this definition, it is understood that there is a human intelligence that can perceive, think, comprehend, analyse, evaluate and make opinions. While forming an opinion about an object, event, situation or problem, people reach a conclusion by evaluating the information from different perceptions and senses in the mind, filter and react accordingly. When it comes to artificial intelligence, one would refer to the analysis, evaluation and automation of data transmitted by artificial receptors to an artificial processing center. However, human intelligence is not only associated with evaluating concrete facts. As a matter of fact, intelligence in psychology is defined as "the sum of abstraction, learning and adaptability to new situations" (TDK, 2020). Is AI capable of perceiving, learning, and analysing such abstract concepts, or is it capable of going beyond? Before answering these questions, it will be useful to look at some definitions on artificial intelligence.

Artificial intelligence is the realization of the artificial simulation of the human thought processes with computers. In a broader sense, it is the term used to refer to a field of science and engineering to produce computational understanding and related mechanisms (such as robots, talking computers) that can be expressed as intelligent behaviour (Adlassnig, 2002: 1-2). Artificial intelligence is the general name of the technology of developing machines that are created with completely artificial tools and that can exhibit human-like behaviours and movements, without benefiting from any living organism. When approached as idealistic; Artificial intelligence products, which can perform things such as feeling completely unique to humans, predicting behaviors and making decisions, are generally called robots (Aydın \& Değirmenci, 2018: 20). Artificial intelligence is, "a science that examines how every cognitive activity (with bodies if necessary) made by natural systems (whether intelligent or not) can do this to artificial systems at even higher performance levels" (Say, 2018:83). Artificial intelligence is defined as trying to develop computer processes that will reveal similarities by understanding the human mind-set. In other words, it is an effort to make a programmed computer to think. According to another definition, artificial intelligence is an intelligence that is computer equipped with capacities specific to human intelligence such as acquiring information, perceiving, seeing, thinking and making decisions (Altuntaş $\&$ Çelik, 2020). According Ersoy (2017: 28), human who cannot keep up with the speed of information, in order to not bear this burden, developed learning robots moving by themselves, make decisions and working without harming any living creatures. No matter what definition we look at, artificial intelligence generally refers to a system based on imitation of human intelligence, behaviours and perceptios by machines.

The summary of other definitions of AI from the past to the present are as follows: "Artificial intelligence; behaviours that are called intelligent when done by humans it is made also by the machine", "A theory that tries to show how the human mind works", "The purpose of artificial intelligence is to imitate human intelligence through computers", "Artificial intelligence tries to understand the structure of intelligence by creating computer programs that control machines." (Pirim, 2006: 83). According to a broader explanation, artificial intelligence is computers equipped with capacities specific to human intelligence such as acquiring information, perception, seeing, thinking and decision making (Altuntaş \& Çelik, 2020).

As can be seen, there are many definitions of AI, but to generalize; it is a design that aims to imitate the intuitive and mental activities of organic life in an artificial or semi-artificial environment first and then to perfection it by making it autonomous.

\section{Management Sciences and Artificial Intelligence}

The concept of artificial intelligence also concerns management sciences since it describes an intelligence, a decision-making center. Therefore, management sciences are also rapidly affected by the developments in the field of artificial intelligence. Today, as a result of this interaction, applications such as natural language interfaces, industrial robots, expert systems and intelligent software have emerged (Altuntaş \& Çelik, 2020). Today's competitive conditions, many businesses and organizations are continuously trying to increase productivity on a sectoral basis by using artificial intelligence techniques. In this competitive environment, managers and employees with every passing day find themselves directly or indirectly in these developments. These systems, which initially have the task of alleviating the human task and workload, gradually take their place in the workforce by deplacing people. 
In the study conducted by Kolbjornsrud et al. (2016) on how artificial intelligence will affect management (fig.1); in 14 countries, percentages of evaluating the working time of middle and top-level managers are determined and accordingly it is stated that managers spend more than half of their time on administrative coordination and control tasks. Executives will want to see most of these tasks (for example, a manager in the store or a head nurse at the hospital must constantly balance shift schedules due to their staff's illnesses, vacations or sudden leave) automated under artificial intelligence burden first.

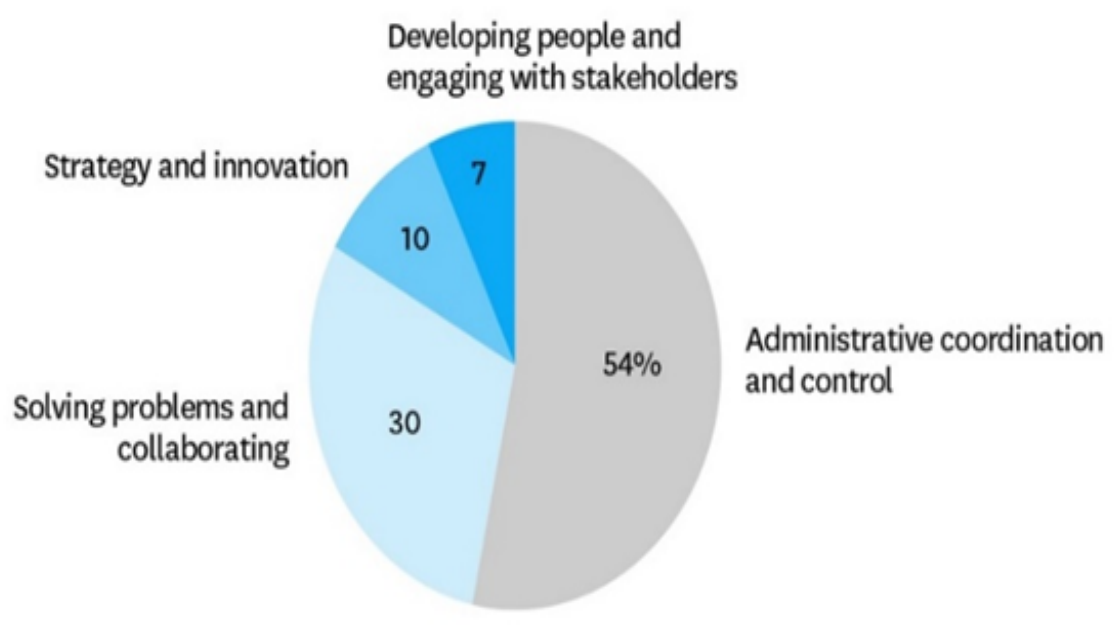

Figure 1. Distribution percentage of manager's category by working time usage (Kolbjornsrud et al., 2016)

The effect of artificial intelligence on management is mentioned by Aksu (2020) as follows: "Artificial intelligence will take away many administrative, bureaucratic, routine, drudgery and repetitive tasks from us. Soon, smart voice assistants in companies will organize meetings, arrange trips, manage permits, call taxis and so on". Aksu (2020) also states that the days of intermediate level managers who convey the instructions, strategies, goals from the top to the underlying teams, are numbered. Smart systems and artificial intelligence-based virtual managers will help employees track their performance in real time, determine their routes, and leave things to chance in no way" (Aksu, 2020). All these predictions point to an effective management model in the way of directing the society to sports activities with more efficient planning, investment and rich service content of artificial intelligence applications in sports.

\section{Artificial Intelligence Studies and Application Areas}

We have stated that artificial intelligence technologies generally emerge by imitating the ability of humans to perceive, think and act. Essentially, AI can perform automated tasks, helping us do things better and faster. Artificial intelligence is a wide research field that includes sciences such as biology, physics, chemistry, medicine, mathematics, as well as sports, arts, linguistics, sociology and psychology. Therefore, the field of artificial intelligence is multidisciplinary and has to work with many sciences (Gültekin, 2006). Those working in the field of artificial intelligence have developed programs that can develop new mathematical theories, improvise jazz music, detect fraudulent financial transactions, collect empty bottles in the laboratory, draw pictures, make medical diagnoses, teach and learn (Gültekin, 2006). There are quite a lot of similar studies and developments of AI under each discipline. However, we can summarize the studies and developments in the field of artificial intelligence under the following headings:

Computer Science: This area of applications focuses on computer software and hardware. Because most of the artificial intelligence applications require the production of very powerful supercomputers. The first stage of this is the intelligent computers known as the fifth generation. These computers are designed for optimum logical interpretation. This inference means using symbolic processing instead of numerical processing in traditional computers (Altuntaş \& Çelik, 2020). While working on quantum computers in the world on this subject, it has unveiled the world's fastest supercomputer "Summit", which was developed in November 2019 by IBM for use in the Oak Ridge National Laboratory and has 
a capacity of 200 petaFLOPS. The "Summit" supercomputer, designed specifically for intensive AI computing and workloads was about 200,000 times more powerful than an average laptop (IBM, 2019).

Robotics: Artificial intelligence, engineering and psychology are the basic disciplines of robotics. Robotics technology has been developed for the production of computer-controlled robots with physical capacities like human beings and is progressing in parallel with the developments in the field of artificial intelligence. Applications in this field give robots the ability to see or visual perception, tactile perception, skill and dexterity in manipulation, mobility and the intelligence to find the way (Altuntaş $\&$ Çelik, 2020). Today, many countries around the world carry out intensive studies in this field. Here is some application examples. The products called "Sophia" (Hanson Robotics, 2020) or "Spot", "Atlas" (Boston Dinamcs, 2020) in the USA and "Akıncı" (Akınrobotics, 2020) developed in Turkish Republic can be given as some examples of the developments in the field of robotics.

Artificial Neural Networks: Artificial neural network studies are designed to perform some functions of the brain and especially learning methods through simulation and give successful results in areas such as classification, clustering, sensory-data processing, and multi-sensory machinery where traditional methods and computers are inadequate. Artificial neural networks need to be trained with a lot of information in order to be used especially in prediction problems. Various algorithms have been developed for training networks (Altuntaş \& Çelik, 2020). In other words, artificial neural networks are parallel and distributed information processing structures, which are inspired by the human brain with similar mentality and each consist processing elements with its own memory. Briefly they are computer programs that imitate biological neural networks (Elmas, 2003). The field of artificial neural networks includes a workspace such as Deep Learning (containing one or more hidden layers and similar machine learning algorithms) and programs such as Keras, Python, TensorFlow, CNTK and Theano are generally used (Bengio, LeCun, Hinton, 2015). Deep learning is an approach used by machines to perceive and understand the world. The confrontation of the artificial intelligence legend is only possible with deep learning. Everything from the automatic scanning of junk e-mails falling in a mailbox to autonomous cars or cancer research without a doctor, is the work of this chain of algorithms (Ayvaz, 2020).

Fuzzy Logic: Fuzzy logic (Fuzzy Logic) can be defined as a rigid mathematical order established to express and work with uncertainties. As it is known, in statistics and probability theory, we work with certainty, not uncertainties, but the environment in which people live is fuller of uncertainties. Therefore, it is necessary to work with uncertainty in order to understand the ability of human beings to draw conclusions. Fuzzy logic has a wide range of applications. The biggest benefit of fuzzy logic outputs is that, the phenomenon of "learning with human experience" can be easily modelled and it allows even ambiguous concepts to be expressed mathematically. For this reason, it is especially suitable for approaching nonlinear systems (Altuntaş \& Çelik, 2020). This technology is used in applications such as cameras, washing machines, air conditioners and automatic transmission lines. It is also used in space research and aviation industry (Korucu, 2007).

Virtual Reality: Virtual reality is a reality created in computer environment and it is also known as "cyberspace". In this field of artificial intelligence is created an environment in which human / computer interfaces are used in accordance with natural reality. The headset, consisting of virtual reality, glasses and stereo headsets, is created based on multi-sensor, input-output devices consisting of a special clothing or gloves that detect body movements. So you can see and touch the three-dimensional virtual world. Virtual reality allows us to interact with computer-simulated objects and assets (Altuntaş \& Çelik, 2020). It also appears as augmented reality and that's live, direct or indirect physical view of the realworld environment, which is created by enriching it with computer-generated images, graphics and sound data. Enrichment occurs in real time and virtual objects interact with the real environment and other virtual objects (Havelsan-1, 2020). The "Havelsan Asger" project can be shown as an example of this technology. "Havelsan Asger" Holographic Command Control System is fictionalized on augmented and virtual reality technologies. Augmented and virtual reality technologies provide to users' interfaces from a different perspective (Havelsan-2, 2020). This technology provides users with a 3dimensional and realistic environment experience by using virtual reality technology in the places they are interested in, without leaving their location. Today, it is gaining popularity in sectors such as Defence, Education, Health, Architecture, Culture-Tourism, Sports and Entertainment.

Internet of Things (IoT): In the Internet of Things technology, every object is connected through detection methods such as RFID, NFC, sensors and WiFi, Wimax, Zigbee, Bluetooth, infrared, etc. 
Information about objects can be obtained with wireless communication techniques. Thanks to this technology, by observing the situations in objects through sensors, such as the temperature, light, pressure, sound, vibration etc. this can serve to think and make decisions of AI (Bozdoğan, 2015). It is also necessary to add wearable technology in this field of artificial intelligence. Today, "wearable technology" comes to mind as the transfer of data obtained from smart sensors of products by connecting them to smart devices wirelessly such as wristbands, watches and necklaces that we wear on our body. Thanks to this technology; Devices that allow access to various useful data for calories, weight loss, heart rate, blood pressure, sugar, daily activity or organizing our work have been developed and put into use. Altra Torin IQ smart shoes (Siddiqui, 2017) or "PrecisionWEAR" brand t-shirt (Siddiqui, 2020) which provides data in 21 different parameters on this subject, is a good example of wearable technology.

Neuromorphic Engineering: Neuromorphic engineering principles is an interdisciplinary subject that is based on the principles of biological nervous systems including biology, physics, mathematics, computer science and electronics engineering, inspiring the design of artificial neural systems such as visual systems, sensing systems, hearing processors and autonomous robots, as well as physical architecture and design (Boddhu and Gallagher, 2012).

The first example of artificial intelligence involved a defined problem, programming based on classical logic within the domain of imitation and rules to draw specific conclusions. That is very suitable for needs such as monitoring processes and improving efficiency. The second, current generation of AI, largely uses deep learning networks to analyse the content of a video frame, perceives and is concerned with that perception. The main focus area of third generation artificial intelligence is neuromorphic engineering, which deals with mimicking the neural structure and functioning of the human brain. It involves probabilistic computing, which creates algorithmic approaches to the problems we have to deal with in the natural world, such as uncertainty and contradiction. Today, "Intel Labs" directs computer science research that contributes to this third generation of artificial intelligence (Intel, 2020). Therefore, the door has not yet been opened in this field of science and it stands before us as the artificial intelligence research area of the future.

Transhumanism: Transhumanism in the dictionary of Larousse (2020) is defined as; a stream of thought that aims to improve human intellectual, physical and psychic capacities by using scientific and technical processes (genetic manipulation, nanotechnologies, artificial intelligence, etc.). However, in the health and psychology glossary (Lexique, 2020) Transhumanism is defined as a sum of neuroscience, biotechnology, genetic engineering, cognitive science, computer science, artificial intelligence and robotics. It is seen as a movement in which several currents aim to increase the physical and intellectual performance of humans. In simpler terms, to improve the sight of a visually impaired person, to activate a paralyzed man with prostheses through a processor and even encouraging his brain to fight against Parkinson's disease covers the areas of work aimed at improving the living conditions of human beings. Transhumanism appears as a set of multidisciplinary studies aimed to rectify and improving certain aspects of human beings such as disability, illness, aging or suffering. One of the latest developments in this field is that with the device developed by "Neuralink", the information coming from the electrical messages of a region of the brain can be monitored with electrodes connected to strings thinner than hair (Musk, 2019). Therefore, the electrical data of our brain could be decoded, read and transferred to the computer.

Artificial intelligence and its work areas can be grouped under very broad headings, as we have mentioned before. This technology has the potential to take an even further dimension. The compact design of attachable or wearable products developed along with bringing all the above-mentioned field developments, will make living things to have different qualities and features. In this case, the living beings will now have to be named as something different. Such beings are referred as "Cyborg" in science fiction movies.

\section{Artificial Intelligence in Sports}

Thinking about the future of sports in the light of the artificial intelligence fields described above and the developments provided, makes us feel that we are on the verge of a development era that will take us to quite deep and different horizons. However, nowadays, we need to plan how to move towards a more efficient and productive future by getting rid of the current bulky structure of the sports industry 
and getting support from the positive aspect of artificial intelligence. As a matter of fact, sports is a field of competition of many countries and those which will take the first steps in this field in sports will be closer to success.

According to Senaar (2019), artificial intelligence applications used in today's sports world are divided into four main categories as chatbots, computer vision, automatic journalism and wearable technology.

Chatbots: Sports teams and sports organizations use artificial intelligence assistants to answer fan's questions on topics such as live game information, team statistics and arena (gym, stadium) logistics. According Senaar (2019), in this way, the audience can go beyond the atmosphere they are inside during competition and can get information about the team or the athletes in real time. In addition, they can access the answers to questions such as where and what situation on the platform they are on.

Computer Vision: Computer vision is an artificial intelligence infrastructure technology that provides information with high speed about the athlete or the vehicle used by them in sports. For example, in an automobile race like Nascar, it is very difficult to determine a sudden damage of the vehicle from the outside, since the speed of the vehicles is very high. However, with Computer Vision, instant photography and machine learning technology, the current status of the vehicle and the equipment that might cause malfunctions can be determined in advance and early intervention can be done. Today, many studies can be developed in the field of sports security via Computer Vision.

Automatic Journalism, betting and information: Artificial intelligence technology can be used for viewers to receive and follow the information about the match according to personal preferences. Artificial intelligence technology can provide personalized information at many points; from electronic ticket purchases from the Internet, to the instant bet notifications. By storing millions of data in artificial intelligence from competitions; weekly, monthly and annual reports can be produced and personal information or competition-oriented betting tactics can be developed. According Sennaar, (2019) all these advantages are reflected in today's media and media outlets can benefit from artificial intelligenceoriented automations to reach customers interested in sports and increase revenue.

Wearable Technology: Organizations use IoT (Internet of Things) devices to increase performance by taking advantage of the data of athletes and teams. Opportunity to create a more efficient training with wearable technology awaits athletes (Sennaar, 2019).

On the other hand, Joshi (2019) states that everything that can be quantified can be predicted precisely by using data analysis and artificial intelligence. It is categorized under 4 titles as; the scouting and recruitment processes of the use of artificial intelligence in sports, training and performance analysis, health and form of athletes and sports publications.

Scouting and Recruitment: According Joshi (2019), although people when they are not measurable according to objective and numerical variables, performance can be studied quantitatively. Sports clubs establish information-processing (discovery) teams examine the performance data of individuals and make an analysis on the potential of the athlete. Among the performance data, not only the main factors of the sport such as the number of goals and baskets, but also much more complex variables are included.

By organizing this complex data with various algorithms, artificial intelligence offers exactly what is desired by the club's computing team. For example; a football club wants to include a football player who can pass quickly and well. Therefore, artificial intelligence offers the most ideal results by examining thousands of historical data. The artificial intelligence, which predicts the current and future potential of the player, gives an idea about the players which they will hire for the club.

Games like Football Manager are examples of artificial intelligence reflected in the game. This game, which has a very large data pool, can almost estimate the real-life potential of football players. It is observed that football players who are successful in the game are also highly successful in real life.

There are also sports science disciplines biomechanics and kinesiology involved in the application areas of artificial intelligence-based methodologies (Lapham and Bartlett, 1995; Bartlett, 2006). On the other hand, in the mobile coaching system, difficult goals are managed more quickly and results are achieved (Baca et al., 2010). These successful AI applications also include different movement evaluations of analytical studies in sports such as golf, baseball, football and basketball (Ghasemzadehet. Al., 2009), (Ghasemzadehet. Al., 2011), (Lamb et. Al., 2010; Bartlett and Lamb, 
2011). In another study, more accurate solutions are presented with artificial intelligence sensors and cameras in swimming talent determination and dynamic system modelling (Silva et. Al., 2007).

Training and Performance Analysis: Coaches and analysts are based on different data according to the player's role in the team, while measuring the player's contribution to the team, states Joshi (2019). For example; while measuring the performance of defender (defence) and striker (attacker) in football, the variables they examine are different. Through artificial intelligence, a reciprocal connection is established between qualitative characteristics (height, weight, etc.) and quantitative variables (pass hit, ball possession rate, etc.). It is possible to estimate the qualitative value of the athlete by measuring these variables. Artificial intelligence can also be used to determine the tactics, strengths and weaknesses of the opponent while preparing for the match. In this way, the coach can create the game plan based on the evaluation of the opposing team, increasing the chances of his team to win. For example, a training scheme could be organized for target-oriented progress in the stable development of artificial intelligence elite biathlon athletes (Baca and Kornfeind, 2012). Some other developments according to the branches are the following:

- In tennis; whatever trainer can see positive and negative in his athlete, he conveys them to his athlete. Thus, he tries to correct his deficiency. Yet this situation is limited to the mistakes that he can observe in his player. It is not possible for the coaches to fully perceive and determine all the positive or negative characteristics of their players. For example, what is the player's pulse rate of every minute of the match? At which angle do the balls hit and at which point do they generally fall in the opponent's area? What are the actor's arm, wrist, and body angles? How are they stepping? What are the body angles of the player in strokes such as forehand, backhand, strike and serve? Artificial intelligence machines such as the hawk eye step in and give us such information, while many people may overlook where the ball hits the line. In addition, the camera attached to the tennis net pole during game, can accurately show whether the service and strike are inside or outside. (Mashinchi, 2020). Additionally, the ball throwing machines that throw balls of different intensity in different directions if there is no opponent in order to provide the tennis player with forehand and backhand development, acting as opponents.

- In football; the main products of artificial intelligence in football is VAR (Video Assistant Referee) system and goal technology systems applied with two goal posts and chip sensors placed on the ball. These systems provide great convenience to the referees by being activated in situations such as goals, offside, violent movements, penalties that the referees cannot see.

- In athletics; time measurements of athletes help to increase performance by intervening in many points such as wind speed, jump and jump intervals. With photocells, artificial intelligence machines can easily keep the seconds that people cannot.

- In Baseball, Cricket, Golf, Fencing; various applications can be made for player development by using smart phones and artificial intelligence. The numbers taken can be counted clearly. The chip placed on the baseball bat determines the angle and timing of the hit. Again, in baseball and cricket, the ball throwing machine can throw balls with the desired hardness (Barr, 2020).

Athlete Health and Fitness: Sports teams make extra efforts for the mental and physical well-being of the athlete. That's why players regularly go through physical tests. Measurements, MRI, x-ray, ultrasound, etc. collected in machines use AI to identify and treat injuries are important for athletes and trainers in determining the injury (www.technogym.com). According to Joshi (2019), by analysing various health variables and movements of the player in the test results, artificial intelligence can detect a possible injury caused by the player's fatigue or stress. Thus, the team's medical and healthcare teams can prevent injury by taking various precautions.

Sports Broadcasts: It is possible to access live broadcasts of almost all sports matches and competitions on TV or the internet. Artificial intelligence allows us to watch the match from an ideal angle by automatically choosing the right camera. Artificial intelligence systems can also identify the right opportunities to serve ads based on the excitement levels of the crowd in sports areas (Joshi, 2019).

Barlow and Sriskandarajah (2019) discuss the application areas of artificial intelligence covering the Sports Industry and its contribution to Sports Management in a broader framework as shown in following Figure 2. 


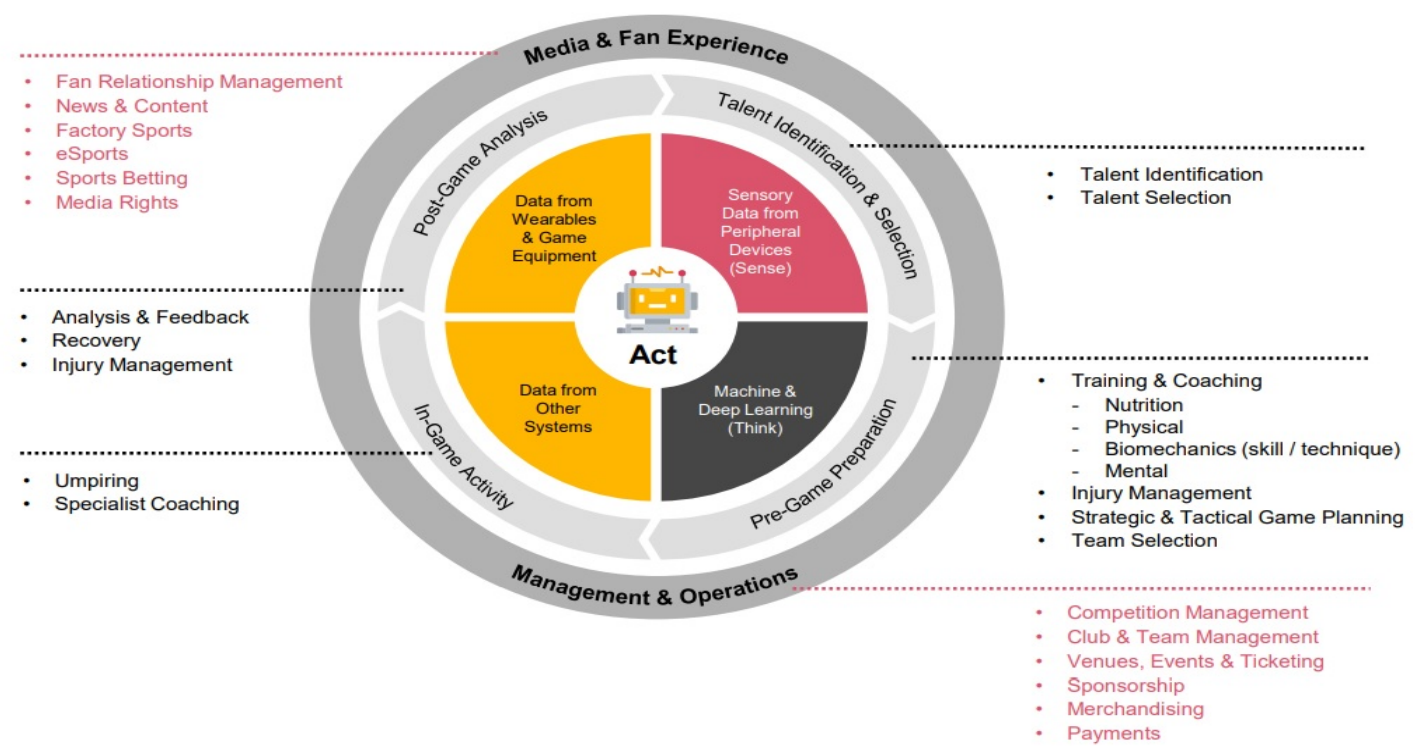

Figure 2. AI Technology Framework for the Sport Industry (Barlow and Sriskandarajah, 2019)

The diagram in Figure 2 above shows where artificial intelligence technology can be used in the sports industry. Here, the data is obtained from wearable devices and equipment during the game activity; by analysing and combining data obtained from peripheral devices such as video and pictures produced from games and training (in real time before or during the game), speech and texts filtered from stakeholders (fans, employees, customers, suppliers, etc.) and data obtained from other internal / external systems. It refers to an AI process that initiates or fully automates better and more efficient decision-making in order to minimize mistakes with task-defined machine and deep learning AI applications aiming to assist coaches, players and managers. (Barlow and Sriskandarajah, 2019).

\section{Future Dimension of Sport Under AI Influence}

It is obvious that artificial intelligence is directing the future of human beings towards a completely different dimension. Almost all branches of science are interested and affected by studies on this subject. Sports sciences are also affected and transformed by the developments in this field, but today there is almost no scientific work in this domain. It seems possible that all layers, including the sports industry will be more deeply affected by artificial intelligence developments in the near future. From this point of view, we can assume that scientific studies in the field of sports will significantly affect the sports industry and its future. Even today, it is observed that some institutions and organizations (clubs, schools, etc.) and a large group of people employed in the sports sector (managers, trainers, athletes) benefit from artificial intelligence technologies that are still in beginning stage. Considering the speed of development and spreading of artificial intelligence we can say that a future for sports experiences of another dimension beyond today's sports awaits us. The future sports managers will perhaps move away from the classic manager and civil servant mentality and appear as a "designer" interested in the development of ethical, social skills and networks in sports clusters.

As explained before, Senaar (2019) states the artificial intelligence applications used in today's sports world under four main categories as chatbots, computer vision, automatic journalism and wearable technology. Joshi (2019) classify it under discovery \& transfer processes, training \& performance analysis, athlete health $\&$ form and sports publications titles. Today, it is possible to gather artificial intelligence under these headings in sports. However, considering that artificial intelligence is a technology that can collect data from every point including athlete and his clothing, opponent, playground and environment, its possibilities of learning, analyse and make prediction, the AI future offers more extensive opportunities. Here are the possible transformations that some basic elements around sports competitions will experience:

Athletes: They will benefit from professional and private life planning, physical characteristics development, match performance tracking, health, nutrition and success level predictions. In this regard, Claudino et al. (2019) conducts a study on the use of artificial intelligence in injury risk assessment and performance prediction in team sports; they conclude that these practices are mostly used to predict 
injury risk and athlete performance in team sports. They state that the most used team sports of these applications are football, basketball, handball and volleyball. They also add that the use of artificial intelligence in team sports has a very promising future (Claudino et al., 2019). Particularly, the use of wearable technology by athletes as in the example of "precisionWEAR" allows them to obtain instant information about their performance levels, and they will be able to share this information with their surroundings (coach, manager, fans, etc.). When the athletes need to improve their performance or make a pre-match preparation, they will have the opportunity to train and compete by choosing their opponents in the virtual space similar to the reality with virtual reality technology as in the example of "ASGER". Other one similar exemple is with the headgear worn in boxing, development can be achieved by boxing with the virtual opponent. Turkish Ski Federation Ski Academy of Economic Simulators which began operating in Istanbul (2017) within the Education Business studies (TKF, 2017) can be indicated here as another current example.

Trainers; artificial intelligence technology offers important developments for the trainers. Thanks to this technology, the coaches will have an important assistant who supports them before, during or after the competition. Coaches can instantly scan from a large pool of the new skills that they will bring to their teams and they can easily access the development by more effective training programs that evaluate the qualitative and quantitative aspects of their players as a result of competition analysis made by AI. For example, it will be easier to plan training accordingly after learning at what point a player has a performance decrease. Artificial intelligence will also be able to provide real and predictive support from game editing, athlete evaluation and playback, strategy determination according to opponents, increasing the competition excitement for the audience.

Referees; today, referees benefit from some technological developments. Referee mistakes may occur especially in huge spectators' sports such as Football, Basketball, and Tennis, where intense supporter pressure is exposed. Nowadays, referee errors are tried to be minimized with applications such as "VAR" system in football. Artificial intelligence can make a very important contribution to this field. Today, refereeing is based rather on human perception. In the near future, information in the game field is expected to be presented by the analysis of data from dozens of sensors covering the competition area making it more accurate. In the beginning, AI will be a good assistant to the referees, but it will not be surprising to see that refereeing is done entirely by artificial intelligence afterwards.

Fans, Betting Players; Those interested in this area become an interactive consumer by experiencing the participation in the virtual competition (Hologram, Virtual reality, Augmented reality technology), path will be opened not only for viewing purposes, but perhaps expressing their ideas and expectations on the game (chatbot and other applications) and also making certain directions. In addition, enthusiasts who are interested in sports and make bets on this subject will also have the opportunity to make a prediction by using artificial intelligence applications. Maybe this will require different measures in the betting industry.

Sports management; whether it is at the club level or at the level of public institutions and organizations, artificial intelligence offers the opportunity to transition to an effective and efficient management. The use of artificial intelligence in sports management has the potential to transform or even eliminate bureaucratic correspondence and routine civil service. General duties in Sports Management stated by Ekmekçi (2013); most tasks such as record keeping, correspondence, public relations, community relations, marketing, sales, organization and information management can be delegated to AI. With the use of artificial intelligence in sports management, the tools, facilities, human and financial resources used in the field of sports will be brought together more efficiently and effectively to provide a betterquality sports service. Artificial intelligence will also offer top management for the opportunity to anticipate possible threats and opportunities.

Sports Media; artificial intelligence promises an autonomous broadcast and presentation in this area as well. Today there has been an improvement up to the "chatbots" used in marketing field and robot TV speakers that analyse videos. Therefore, with the adaptation of this technology to sports, we may have the opportunity to see the transition to an autonomous sports media in artificial intelligence management in the near future like Senaar (2019) has mentioned before. As a result, sports journalism and reporting are likely to be among the disappearing professions in the future.

Sports Facilities and Venues; it will stand out as the places where artificial intelligence applications take place the most. Since sports training and competitions take place in this area, these areas will be entangled with tens or even hundreds of sensors (Internet of Things) and the data filtered from these 
places will be evaluated by artificial intelligence. It will be necessary to talk about smart facilities here. Sports venues specially defined for individuals or teams, facilities that can automatically adjust their temperature, lightness, cleanliness, safety, working and closing time will transform our future and our quality of life. In addition, by using hologram technology in the facilities, services can be provided from a distance for important competitions. Thus, the competitions can reach the local audience live without the need to travel long distances to watch a match.

As can be seen, it is possible to list the innovations and advantages of artificial intelligence technologies and applications for each element or task area of the sports industry and to put them into longer texts. In order to understand the effect of artificial intelligence on sports, it will be sufficient to limit the sports competition to the stakeholders surrounding it as above. To put it briefly; Artificial intelligence applications in sports will deeply affect the sport activity and its surrounding stakeholders. Thanks to artificial intelligence applications in sports, high-level organizations, activities and training diversity will be provided and this will realize an advantage to the future sport phenomenon. Even today, developments in information and communication technologies, data and information obtained from wireless network sensors, automatic analysis parameter measurements are the developments that can be easily achieved by trainers, athletes and hobbyists in professional and amateur sports using mobile phones, computers and other electronic measurement tools. (Novatchkov, 2013).

While talking about the advantages of artificial intelligence, we should not forget about the possible disadvantages. For example, some professions will transform and some will disappear, which is a disadvantage on employment. Yet the question to be asked here is if we leave the management in sports to artificial intelligence, to what extend can we have concepts such as ethics, morality and fair play in sports? How correct would it be to leave these values to the machines which people developed over many years? What will the artificial intelligence management, motivated only by the goal of winning bring to society? How will concepts such as "common sense", "good intention", "conscience", "aesthetics", "humanism" be affected and how can these values be preserved? Will artificial intelligence, which has entered in lives of sports and athletes more, make the sports competitions and activity that people enjoy and practice today meaningless? Is artificial intelligence threatening today's athlete profile? Such questions occur in the human mind.

Before we put an end to our study, it will be useful to share the news that Günyol (2020) compiled for Anadolu Agency, undern the title "The age of half human, half robot entities is coming":

The new technology, which was started by the technology company Sony and enabled taking photographs and video recordings with a lens placed in the eye, had a great impact on the internet. The new lens, patented by Sony, will be activated according to the user's blinking movements and will be able to record photos and videos on demand.

Ben Goertzel, founder of SingularityNET, explain the inevitability of technology devices entering the human body; "imagine you have a daughter and all the other kids in the class are better than her. Because the brains of other children can connect directly to Google or the calculator and communicate with each other, your child is back between them. She has to do everything with outmoded methods and is unable to message her friends from brain to brain. The class teacher says that your daughter cannot be in this class anymore. What would you do in such a situation? Transhumanism is not an intellectual subject and becomes a necessity at this point and begins to come" used the expressions.

Tesla manager (CEO) Elon Musk states that the only way out of people being captured by computers will be a system where computers can combine with the human brain. Using the phrase "the scenario of merging with artificial intelligence is the best we have right now", Musk said that with the new brain implant he announced yesterday, the human brain can connect with machines. Musk emphasized that the only way of salvation for the human brain, which is thought to be left behind by the artificial intelligence, is a brain with a computer connection" (Günyol, 2020).

As can be seen, the combination and mutual interaction of artificial intelligence and some human organs is now mentioned. It is clear that the time has come for the cyborg (artificial beings) or transhuman individuals mentioned above. Günyol (2020) states that, developments in the field of artificial intelligence causing thought that robots will replace human beings, actually with the studies on transhumanism where is the robot-human mixture (cyborgs) of the future. In a world where people benefit from an unlimited pool of information based on artificial intelligence with nanochips, they are 
guided and talk telepathically with other living and non-living devices. From the point of view of sport, it is clear that today's natural sports cannot be talked about, but rather technological sports (Technosport) will be discussed. Therefore, it would be appropriate to evaluate sports that are integrated with artificial intelligence under other concepts and categories such as "Technosport, Cyborsport etc.." for the protection of today's natural sports concept.

\section{CONCLUSION}

From the concept of artificial intelligence in sports, it can be understood that all elements surrounding the sport and the athlete such as: equipment, team, club, institution, organization, media, facility, bureaucracy are programmed for the specific purpose and goals of sport organization. At this stage, when all these interconnected or non-interconnected elements remain in interaction and governance with each other and perform their duties and activities automatically, we can talk about a general artificial intelligence management in sports.

As a result, it is seen that artificial intelligence applications in sports can have positive and negative consequences on the sports industry. In the near future, if we want to make today's sports events sustainable and spectacular with the same excitement and enthusiasm, it will be necessary to keep the effect of artificial intelligence on athlete to a minimum level. Artificial intelligence will highlight the added feature rather than the skill of the athlete. From the other side, artificial intelligence can be the basic and most useful tool surrounding the sport and its events. By including AI to task of referee, broadcasting, supervising, security etc. it can contribute to the execution of sports competitions more regularly, punctually and accurately.

Considering that artificial intelligence may have an important function in sports competitions in the future, it may require some drastic measures, as in the current fight against doping, especially as it will create a fraudulent situation in the intervention of the athlete. In this regard, during today's transitional period of AI the national and international organizations already have important duties. In particular, it is hoped that the International Olympic Committee will assume certain obligations in this regard, due to its worldwide organization and global influence.

With this study, it has been tried to reveal the positive and negative effects that may rise in the sports sector by examining the sports dimension together with the artificial intelligence studies carried out today. In terms of the sustainability of today's sports, it is necessary to encourage original and qualified studies in areas that include artificial intelligence and the social dimensions of sports.

\section{PRACTICAL APPLICATION}

Artificial intelligence and software studies that advance within the framework of ethical rules and prioritize human, animal and other lives should be supported.

\section{REFERENCES}

Adlassnig, K.P. (2002). Artificial-intelligence-augmented systems (Editorial). Artificial intelligence in medicine. 24(1), 1-4.

Akınrobotics. (2020). Akınc1. Retrieved from: https://www.akinrobotics.com/tr/hakkimizda,

Aksu, H. (2020). Türkiye Yapay Zeka İnisiyatifi (TRAI). Retrieved from: https://turkiye.ai/yapayzeka-etkisi-ara-kademe-yonetici-kalmayacak/

Altuntaş, E. \& Çelik, T. (2020). Yapay Zeka. Retrieved from: http://bagem.tripod.com/bagem/yz3.html

Aydın, İ. H., \& Değirmenci, C. H. (2018). Yapay Zeka. İstanbul: Girdap Yayınları.

Ayvaz, T. (2020). Deep learning, derin öğrenme nedir? Retrieved from: https://www.mediaclick.com.tr/blog/deep-learning-derin-ogrenme-nedir.

Baca, A., \& Kornfeind, P. (2012) Stability analysis of motion pattern in Biathlon shooting. Human Movement Science 31(2), 295-302.

Baca, A., Kornfeind, P., Preuschl, E., Bichler, S., Tampier, M., \& Novatchkov, H. (2010). A server based mobile coaching system. Sensors (Basel, Switzerland). https://doi.org/10.3390/s101210640.

Barlow, A., \& Sriskandarajah, S. (2019). Artificial intelligence application to the sports industry. Retrieved from: https://www.pwc.com.au/industry/sports/artificial-intelligence-application-tothe-sports-industry.pdf 
Barr. G. (2020). How artificial intelligence plays into the future of sports technology. Retrieved from: https://www.sporttechie.com/artificial-intelligence-plays-future-sports-technology/

Bartlett, R. \& Lamb, P. (2011). The use of artificial neural networks in studying movement coordination. In: Proceedings of 8th international symposium of the international association of computer science in sports. Shanghai, China. 22-33.

Bengio, Y., LeCun, Y., \& Hinton, G. (2015). Deep learning. Nature journal. 521 (7553), 436-444.

Boddhu, S. K., \& Gallagher, J. C. (2012). Qualitative functional decomposition analysis of evolved neuromorphic flight controllers. Applied Computational Intelligence and Soft Computing. (6). 121. https://doi.org/10.1155/2012/705483.

Boston Dynamics. (2020). Spot. Retrieved from: https://www.bostondynamics.com/about,

Bozdoğan, Z. (2015). Nesnelerin interneti için tasarim mimarisi. (Yüksek lisans tezi), Düzce Üniversitesi Fen Bilimleri Enstitüsü, Düzce 37.

Claudino, J.G., Capanema, D.D., De Souza, T.V. et al. (2019). Current approaches to the use of artificial intelligence for injury risk assessment and performance prediction in team sports: a systematic review. Sports Med - Open. 5, 28. https://doi.org/10.1186/s40798-019-0202-3

Ekmekçi, R. (2013). Spor yönetimi. Yayın no: 2883. Eskişehir: Anadolu Üniversitesi yayınevi.

Elmas, Ç. (2003). Yapay sinir ağları. Ankara: Seçkin yayınevi.

Ersoy, Ç. (2017). Robotlar, yapay zeka ve hukuk. İstanbul: Onikilevha Yayınları.

Ghasemzadeh, H., \& Jafari, R. (2011) Coordination analysis of human movements with body sensor networks: A signal processing model to evaluate baseball swings. IEEE Sensors Journal 11(3), 603-610.

Ghasemzadeh, H., Loseu, V., \& Jafari, R. (2009) Wearable coach for sport training: A quantitative model to evaluate wrist-rotation in golf. Journal of Ambient Intelligence and Smart Environments. 1, 1-12.

Gültekin, Ö. (2006). Satranç ve yapay zeka tartişmalarindaki yeri, Journal of Istanbul Kültür University, 2006/3, 119-128.

Günyol, A. (2020). Yarı insan, yarı robot varlıkların çağı geliyor. Anadolu Ajamsı. Retrieved from: https://www.aa.com.tr/tr/bilim-teknoloji/yari-insan-yari-robot-varliklarin-cagi-geliyor/1534954

Handley, L. (2020) Zhang Zhao artificial intelligence speaker. Retrieved from: https://www.cnbc.com/2018/11/09/the-worlds-first-ai-news-anchor-has-gone-live-in-china.html,

Hanson Robotics. (2020). Sophia. Retrieved from: https://www.hansonrobotics.com/sophia-2020/

Havelsan-1, (2020). Artırılmış Gerçeklik. Retrieved from: https://www.havelsan.com.tr/innovation/yeni-teknolojiler/inovasyon-ar-ge/artirilmisgerceklik/arttirilmis-gerceklik,

Havelsan-2, (2020). ASGER. Available from: https://www.havelsan.com.tr/sektorler/savunma-veguvenlik/kara/arttirilmis-gerceklik/havelsan-asger,

IBM. (2020). Summit. Retrieved from: https://www.ibm.com/ibm/responsibility/initiatives/activitykits/summit/,

Intel, (2020). Neuromorphic computing. Retrieved from: https://www.intel.com.tr/content/www/tr/tr/research/neuromorphic-computing.html,

Joshi, N., (2019). Here's how A.I. will change the world of sports. Retrieved from: https://www.forbes.com/sites/cognitiveworld/2019/03/15/heres-how-ai-will-change-the-worldofsports/?fbclid=IwAR27gUj_p0t1byFDrwTQNBwX9YDn2OAtpfL3AGukZCmmUdkxiFkIPrZ_ ung\#18a13c3f556b/Translation: Çakmak, S. Retrieved from: http://inovasyon101.com/yapayzeka-spor/

Karaduman, T. (2019). Yapay zekâ uygulama alanlari. Retrieved from: https://www.academia.edu/16703256/Yapay_zeka_makale_09_06, 1-11.

Kolbjornsrud, V., Amico R., \& Thomas, R. (2016). How artificial intelligence will redefine management. Harvard Buziness Review. 2, 1-6.

Köroğlu, Y. (2017). Yapay Zeka'nın teorik ve pratik sınırları. 6. Evrim, Bilim, ve Eğitim Sempozyumu. İstanbul.

Korucu, A, T. (2007). Bulanık mantik problemleri için türkçe görsel bir arayüz tasarimi. (Yüksek Lisans Tezi), Selçuk Üniversitesi, Konya.

Lamb, P., Barlett, R., \& Robins A. (2010). Self-Organising Maps: An Objective Method for Clustering 
Complex Human Movement. International Journal of Computer Science in Sport, 9(1), 20-29.

Lapham, A. \& Barlett, R. (1995). The use of artificial intelligence in the analysis of sports performance: A review of applications in human gait analysisand future directions for sports biomechanics. Journal of Sport Sciences, 13, 229-237.

Larousse. (2020). Definition de transhumanizm. Retrieved from: https://www.larousse.fr/dictionnaires/francais/transhumanisme/188207,

Lexique. (2020). Definition de transhumanizm. Retrieved from: http://www.psychomedia.qc.ca/lexique\#lexicon-tacite,

Mashinchi, J. (2020). How AI can help improve sports performance. Retrieved from: https://www.cambridge-design.com/news-and-articles/blog/how-ai-can-help-improve-sportsperformance

Musk, E. (2019). An integrated brain-machine interface platform with thousands of channels. Retrieved from: https://www.biorxiv.org/content/10.1101/703801v4.full.pdf,

Novatchkov, H., \& Baca, A. (2013). Artificial intelligence in sports on the example of weight training. Journal of sports science \& medicine, 12(1), 27-37.

Pirim, H. (2006). "Yapay Zeka", Journal of Yaşar University. 1(1), 81-93.

Roy, B. (2019). How the application of artificial intelligence (AI) and machine learning (Ml) impacting sports. Retrieved from: https://towardsdatascience.com/ai-augmented-sports-revolution5c0727ba7004,

Say, C. (2018). 50 soruda yapay zeka. İstanbul: 7 Renk Basım Yayın.

Sennaar, K. (2019). Artificial intelligence in sports - current and future applications. Retrieved from: $\mathrm{https://emerj.com/ai-sector-overviews/artificial-intelligence-in-sports/}$

Siddiqui, A. (2017). Altra Torin IQ smart shoes - your running coach. Retrieved from: https://www.sportswearable.net/altra-torin-iq-smart-shoes-running-coach/

Siddiqui, M. (2020). PrecisionWEAR: The A.I. run sports wearable. Retrieved from: https://www.sportswearable.net/precisionwear-i-run-sports-wearable/

TDK. (2020). Zeka nedir? Retrieved from: https://sozluk.gov.tr.

Technogym. (2020). Future sport. Retrieved from: https://www.technogym.com/int/newsroom/futuresport/

TKF. (2017). Kayak akademisi - simülatörlü eğitim. Retrieved from: https://www.tkfkayakakademisi.com/simulatorlu-egitim.html,

\section{CITATION OF THIS ARTICLE}

Atasoy, B., Efe, M., \& Tutal, V. (2021). Towards the Artificial Intelegence Management in Sports. International Journal of Sport, Exercise \& Training Sciences - IJSETS, 7(3), 100-113. Doi: 10.18826/useeabd.845994 